Noticias

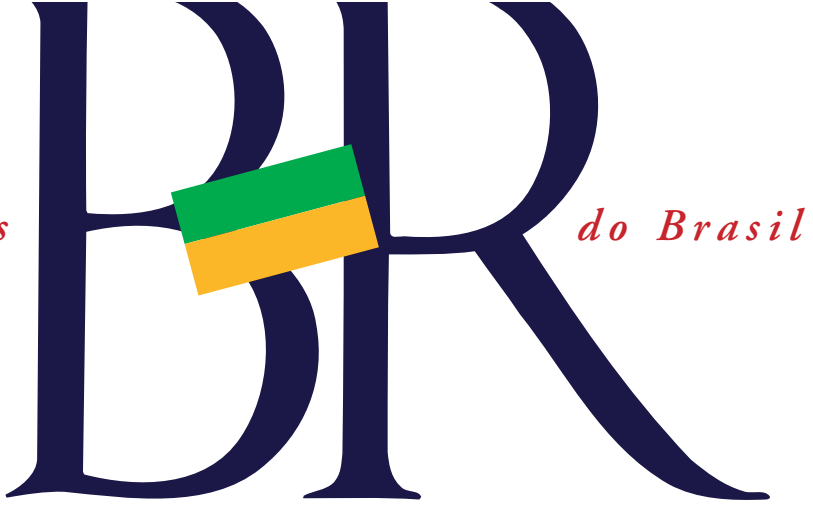

vezes, dividem as tarefas do

museu com as de docente universitário. Hoje, existem cinco cursos de pós-graduação em museologia no país (três mestrados, um doutorado e dois mestrados profissionais), de acordo com a Capes, apenas um voltado para a área de preservação de acervos de ciência e tecnologia, do Museu de Astronomia (Mast), que ainda aguarda homologação. "Hoje, precisamos ainda de mais formação continuada e permanente dos profissionais e que a população se aproprie desses espaços. Precisamos tornar públicos esses ambientes", defende o presidente da $A B C M C$, com a concordância do diretor do museu da UFMG.

Para Roseli de Deus, da USP, apesar do engajamento das equipes de museus no país, é preciso investir em profissionalização, ampliar o público e firmar parcerias públicoprivadas de modo a garantir a sustentabilidade e a atualização das instituições. "Estes espaços precisam ser inseridos em políticas de Estado, enquanto espaços de educação não formal, de grande importância tanto para o público escolar como para o público geral", defende.

Germana Barata Colaboração Giselle Soares
TrANSGÊNICOS

\section{Proposta quer limitar informação nos rótulos}

O Artigo 40 da Lei de Biossegurança (11.105/05) determina que os alimentos e ingredientes alimentares destinados ao consumo humano ou animal que contenham ou que sejam produzidos a partir de transgênicos, deverão conter essa informação em seus rótulos. Transgênicos são produtos alimentares derivados de plantas transgênicas ou OGMs (Organismos Geneticamente Modificados). São plantas que tiveram inseridos em seu genoma um ou mais genes oriundos de outra espécie, conforme explica Antonio Orlando Di Mauro, professor da Faculdade de Ciências Agrárias e Veterinárias, da Universidade Estadual Paulista "Júlio de Mesquita Filho" (Unesp), de Jaboticabal. Hoje é possível identificar a letra $\mathrm{T}$, dentro de um triângulo amarelo com bordas pretas, em vários produtos, como bolachas, óleo, cereais matinais, massas, margarinas, indicando que aquele alimento possui ingredientes transgênicos. Porém, em abril deste ano, a Câmara dos Deputados aprovou um Projeto de Lei (4.148/08) que limita essa medida: os produtos não precisam mais exibir o símbolo " $\mathrm{T}$ ", mas apenas conter a informação

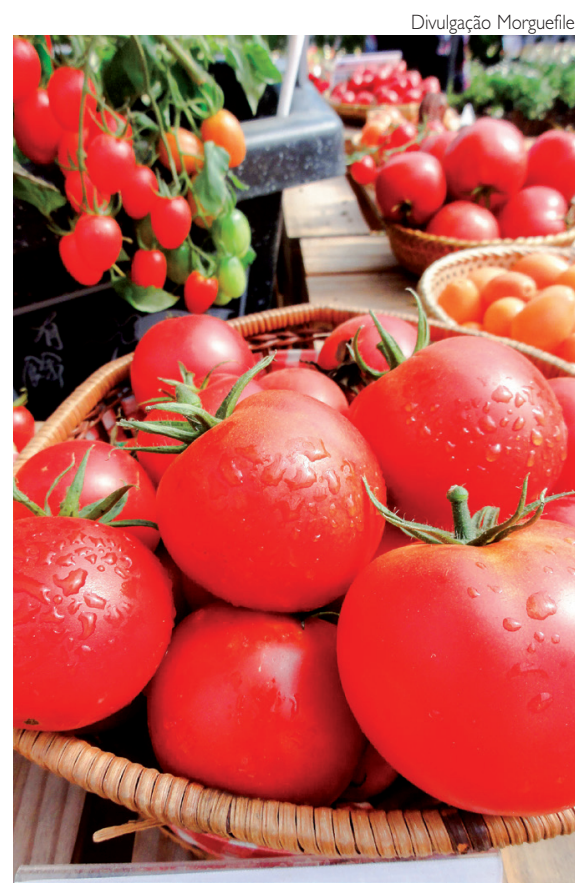

Tomate foi o primeiro alimento transgênico a chegar aos supermercados

de que o alimento foi feito com algum ingrediente transgênico com presença superior a $1 \%$ de sua composição final, detectada em análise específica. A proposta, de autoria do deputado Luiz Carlos Heinze (PP-RS), ainda tem que ser aprovada no Senado. "É importante frisar que o projeto não extingue os rótulos, mas os limita, enquanto que, na legislação vigente, não há previsão de qualquer porcentagem, sendo a informação sempre exigida”, explica Iara Antunes de Souza, doutora em direito privado e professora $\mathrm{da}$ Universidade Federal de Ouro Preto (Ufop). A justificativa do projeto é que o símbolo do "T" em um tri- 


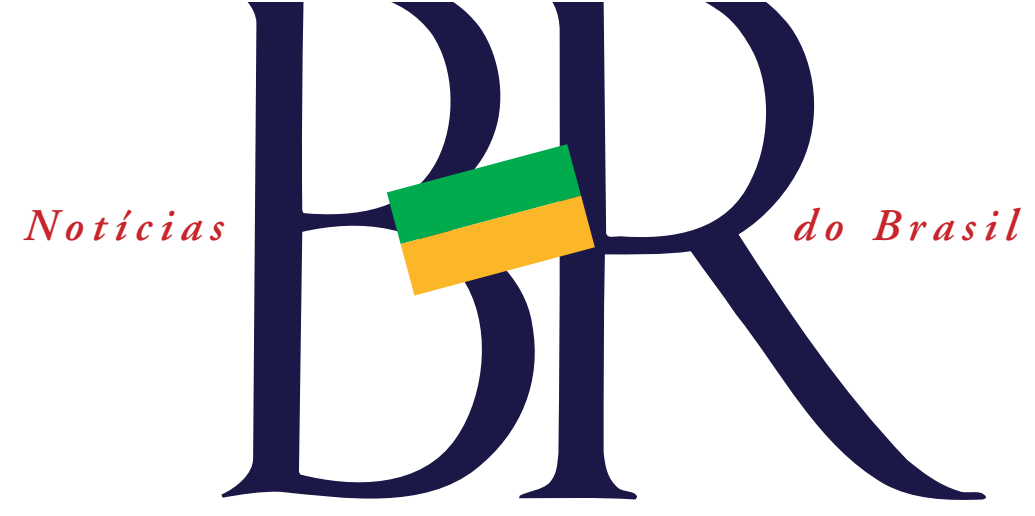

ângulo pode levar à noção de perigo, confundindo o consumidor.

DIREITO À INFORMAÇÃO E, como fica o consumidor caso essa mudança seja, de fato, efetivada? Souza explica que o Código de Defesa do Consumidor (Lei n. 8.078/90) prevê: "[...] a informação adequada e clara sobre os diferentes produtos e serviços, com especificação correta de quantidade, características, composição, qualidade, tributos incidentes e preço, bem como sobre os riscos que apresentem”. A pesquisadora defende, portanto, que a presença de OGM deve ser informada para ajudar o consumidor a optar por consumir, ou não, o produto.

$\mathrm{Na}$ União Europeia, a indicação nos rótulos é obrigatória para produtos que contenham ao menos $0,9 \%$ de OGM em sua composição. Nos Estados Unidos começam movimentos pela rotulagem com informações sobre OGM nos produtos: no parlamento de Vermont, por exemplo, foi aprovada a primeira lei, que ainda precisa ser aprovada pelo governador desse estado.

POLÊMICo O projeto aprovado na Câmara Federal é bastante polêmico porque não há resultados conclusivos sobre as consequências do consumo de alimentos com ingredientes transgênicos. "Não existem pesquisas conclusivas acerca dos efeitos do consumo de organismos geneticamente modificados por seres humanos, em especial para as geraçôes futuras. Por isso, seria o caso de aplicar o princípio da precaução do biodireito, que determina que as consequências ainda não conhecidas pela ciência devem ser evitadas, exceto se houver anuência da pessoa. Se não houver a informação, ainda que a quantidade de OGM seja menor que $1 \%$, a pessoa não poderá exercer sua autonomia privada de optar ou não por consumir", afirma Souza.

O uso de tecnologias de modificação do gene na produção de alimentos tornou-se atraente por conta da necessidade de produzir mais alimentos e de melhorar sua qualidade. De acordo com Tânia Aparecida Pinto de Castro Ferreira, professora da Faculdade de Nutrição, da Universidade Federal de Goiás (UFG) e doutora em ciência dos alimentos, "Com a aplicação da tecnologia genética em plantas e animais, esses objetivos podem ser alcançados mais rapidamente do que pelos métodos tradicionais de seleção de plantas para produção de novas geraçôes". Entretanto, segundo ela, muitas questôes ainda perduram: "que efeitos a manipulação de genes terão no meio ambiente, especialmente em longo prazo? $\mathrm{O}$ que deve ser informado para os consumidores em termos de saúde? A tecnologia recombinante é realmente benéfica pesando todos os prós e os contras?", questiona a pesquisadora.
HÁ 20 ANOS Consumimos alimentos transgênicos desde 1994, quando foi produzida a primeira planta transgênica, uma variedade de tomate que resistia mais tempo nas prateleiras dos supermercados. "No início da criação dos transgênicos existia certo risco porque a seleção dos tecidos era feita em meios de cultura que continham antibióticos, como a kanamicina", esclarece Di Mauro. "Nesse caso, a resistência ao antibiótico poderia ser transferida para as bactérias do solo e, eventualmente, chegar até as bactérias hospitalares. Daí a polêmica. Hoje esse processo de seleção é diferenciado e não envolve mais o uso de antibióticos ou de qualquer substância nociva à saúde", complementa. Mesmo assim, ele acredita que manter a rotulagem é simplesmente respeitar o direito do consumidor. "Creio que, independente de ser transgênico, orgânico ou de outra natureza é um direito do consumidor saber em detalhes o que está adquirindo", afirma. Ferreira considera o projeto de lei um retrocesso. "Enquanto não temos certeza sobre quem está certo, a regra deveria ser uma só: transparência. Todo mundo deveria ser capaz de identificar facilmente alimentos produzidos através de bioengenharia, no rótulo, para poder escolher se quer ou não consumi-los".

Patricia Piacentini 